\title{
Study of Champua watershed for management of resources by using morphometric analysis and satellite imagery
}

\author{
A. K. Prabhakar ${ }^{1}$ K. K. Singh ${ }^{1}$ - A. K. Lohani ${ }^{2}$ 'S. K. Chandniha ${ }^{3}$
}

Received: 19 July 2017 / Accepted: 13 June 2019 / Published online: 25 June 2019

(C) The Author(s) 2019

\begin{abstract}
The water resource management is a present need for sustaining the living environment on a watershed. The anthropological activities on any watershed cause resources imbalance that eventually affects the watershed performance. Remote sensing and geographical information system are the powerful tools to identify such changes in the watershed either by natural causes and/ or by human intervention. Such knowledge is useful for scientific planning and management of watershed. The present study has been highlighted the morphometric analysis with land use and land cover (LULC) changes and hydrologic performance during 2001 and 2011 over the Champua watershed of Upper Baitarani river basin, Odisha, India. The various parameters of morphometry which cause soil erosion have been evaluated and are used to prioritize the sub-watersheds. Also, LULC changes from two satellite imaginaries of the years 2001 and 2011 have been classified and percentage area changes of the respective classes for the sub-watersheds over one decade have been estimated. Then, various land features which would increase runoff and cause more soil erosion have been evaluated to prioritize the sub-watershed. Finally, prioritization is assigned for sub-watersheds, according to severity effects due to morphometric parameter and LULC changes. To archive for management point of view, the conservation practices or measures are recommended as per their final priority. These results obtained from prioritization of sub-watershed would be useful for hydraulic engineers for planning and management.
\end{abstract}

Keywords Morphometry $\cdot$ LULC change $\cdot$ Sub-watershed $\cdot$ Priority $\cdot$ Remote sensing $\cdot$ GIS

\section{Introduction}

Water is a basic resource for everyone who lives on the earth; however, human beings require freshwater for its survival and sustenance. The availability of freshwater on earth is limited. The demand for water is increasing day by day due to increasing population, industrialization and improvement in quality of life. Thus, all the freshwater sources are under pressure due to demand. The rainfall is the external entry that maintains freshwater on the watershed. Therefore, proper scientific planning and management of freshwater can only sustain demand of increasing population for food

A. K. Prabhakar

ajayprabhakar2@gmail.com; akprabhakar@nitkkr.ac.in

1 Department of Civil Engineering, National Institute of Technology, Kurukshetra, India

2 Surface Water Hydrology Division, National Institute of Hydrology Roorkee, Roorkee, Uttarakhand, India

3 Department of Soil and Water Engineering, Indira Gandhi Krishi Vishwavidyalaya Raipur, Raipur, Chhattisgarh, India and other needs. Watershed deterioration is a common issue in the most part of the world including India. A watershed is a natural hydrological unit that generates surface runoff from the rainfall which flows through channel, streams, river, lakes or oceans (Chopra et al. 2005). Due to excessive runoff, soil erosion and flood may occur over the watershed which are highly disastrous. The soil erosion reduces the productivity of land and capacity of the river which can cause flood. The runoff depends on surface characteristics of catchment; therefore, morphometry analysis can play a vital role in finding out the characteristics of watershed (Tripathi et al. 2003). In morphometric analysis, drainage basin and its stream channel arrangement can be well understood through various features (Horton 1945) such as stream length, stream order, bifurcation ratio, stream frequency, form factor, circulatory ratio, elongation ratio, texture ratio, compactness coefficient, relief ratio, length of overland flow and drainage density (Nag and Chakraborty 2003). Morphometric parameters mainly depend upon lithology, bed rock and geological structures. Hence, the information on geomorphology, hydrology, geology and land-use pattern 
is highly informative for reliable study of drainage pattern of the watershed (Astras and Soulankellis 1992; Binjolkar and Keshari 2007).

Geospatial techniques such as remote sensing (RS) and geographical information system (GIS) are the powerful tools for the analysis of the drainage pattern of watershed. They are quite efficient for prioritization of sub-catchment for water resource modeling and flood management (Youssef et al. 2011; Miller and Kochel 2010; Bali et al. 2012). Many researchers (Ratnam et al. 2005; Gupta and Srivastava 2010; Srivastava et al. 2010; Pandey et al. 2012; Srivastava et al. 2012 and Thakur et al. 2012) have been suggested that the morphometric analysis is quite helpful for finding the appropriate site location for soil and water conservation structures i.e., check dam, trenches, pits, farm ponds, spillways etc. Bagyaraj et al. (2011) used these tools for forecast and assessment of high runoff in the sub-watershed. Dawod et al. (2012) estimated erodibility of the catchment. Arun et al. (2005) gave the rule-based physiographic characterization of a drought-prone Gandeshwari watershed in Bankura district of West Bengal by using the remote sensing and GIS techniques. Turkelboom et al. (2008) dealt the problem of land degradation and water balance. Danida (1988) recognized semiarid region problems of soil erosion, reduction in productivity and eruption of change in an ecosystem. The land use and land cover (LULC) changes also affect the regional climates through changes in surface characteristic and water balance. The evapotranspiration rate increases due to increase in agriculture and forest areas; as a result, the maximum temperature decreases and irrigation increases the heat capacity of the soil (Pielke et al. 2002; Kalnay and Cai 2003), which raises the minimum temperature. Therefore, both agriculture and afforestation would increase minimum temperature and decrease maximum temperature. The surface runoff and river discharge after the precipitation generally increase due to decrease in shrubland and forest (Sahin and Hall 1996; Costa et al. 2003). This positive/negative change would affect the watershed. The random LULC changes disturb the hydrological cycle with the passage of time. The knowledge of climate, topography and land cover which affect the soil erosion process (Gabarrón-Galeote et al. 2013; Lieskovský and Kenderessy 2014) is useful for sustainable management of land. The conservation practices or measures can be applied over the watershed by assigning the priority to the Piperiya sub-watershed which originated from Hasdeo River catchment of Mahanadi basin in Chhattisgarh state in India (Chandniha and Kansal 2017). The critical sub-watersheds for Nagwan watershed in east India were identified by Tripathi et al. (2005) and then prioritized on the basis of annual soil losses. Indirasagar canal command area of Madhya Pradesh is one of the sucess story to survival of agricultural crops througout the year with sustainable management of land and water resources with maximum benifit and cost ratios (Prabhakar and Tiwari 2015). Therefore, the water availability and soil erosion can be managed by scientific planning over the watershed.

Further, it has been noticed that during last few decades, climate in various river basins of India has been changing which affects its water availability by Mujumdar (2008) and Raje and Mujumdar (2009). In order to study the impact of land use changes, a watershed known as Champua lies in Keonjhar district of Odisha is selected, which is part of Baitarani river basin. This river basin has been frequently facing drought (2000, 2002, 2010 and 2015; https://farmer.gov.in/Drought/ Droughtreport.aspx and floods (1960, 1961, 1964, 1971, 1974, 1984, 1991, 1995, 1997, 2003, 2006 and 2008; http://www. dowrorissa.gov.in/HistoryofFLOOD). The tribal population living within this sub-plane area depend upon agricultural produce for their food and income. The area is highly underdeveloped due to inefficient management of irrigation facilities in the basin. It has been noticed that most of the prioritization analysis has been done with digital elevation models, but in present study has been done with help of both digital elevation model and LULC which provide quite better results as compared to previous methodologies. The objective of the study is to use LULC and morphometric analysis together for prioritization. These results will be useful for more reliable planning and management of watershed for sustaining the life.

\section{Study area}

The study area, the Champua watershed adopted in this study, is part of Upper Baitarani river basin located in Odisha state of India. The study area lies between $85^{\circ} 9^{\prime} 42.66^{\prime \prime}$ and $85^{\circ} 44^{\prime} 10.42^{\prime \prime} \mathrm{E}$ longitude and $21^{\circ} 6^{\prime} 52.92^{\prime \prime}$ and $22^{\circ} 11^{\prime} 51.65^{\prime \prime} \mathrm{N}$ latitude. Location map of the area is given in Fig. 1. It covers a geographical area of about $1815 \mathrm{~km}^{2}$ with topographic elevation ranging from 340 to $1109 \mathrm{~m}$. The watershed covers the three districts (Kendujhar, Sundargarh and Angul) of Odisha and partially intersects the Singhbhum district of Jharkhand state. However, the major part is covered under the Kendujhar district of Odisha. The Baitarani River generally flows in eastward direction of the Peninsular India and finally drains into the Bay of Bengal. The river rises in the hill ranges of Kendujhar district of Odisha near the Manakarancho village at an elevation of about $900 \mathrm{~m}$ above M.S.L. The annual average rainfall of the catchment is about $1438 \mathrm{~mm}$ and Kendujhar district is about $1505 \mathrm{~mm}$. Cultivation is the basic source of livelihood for rural masses, and most of the living population is tribal community.

\section{Methodology}

This paper is organized into two different methods of analysis which involves morphometric and land use and land cover. 


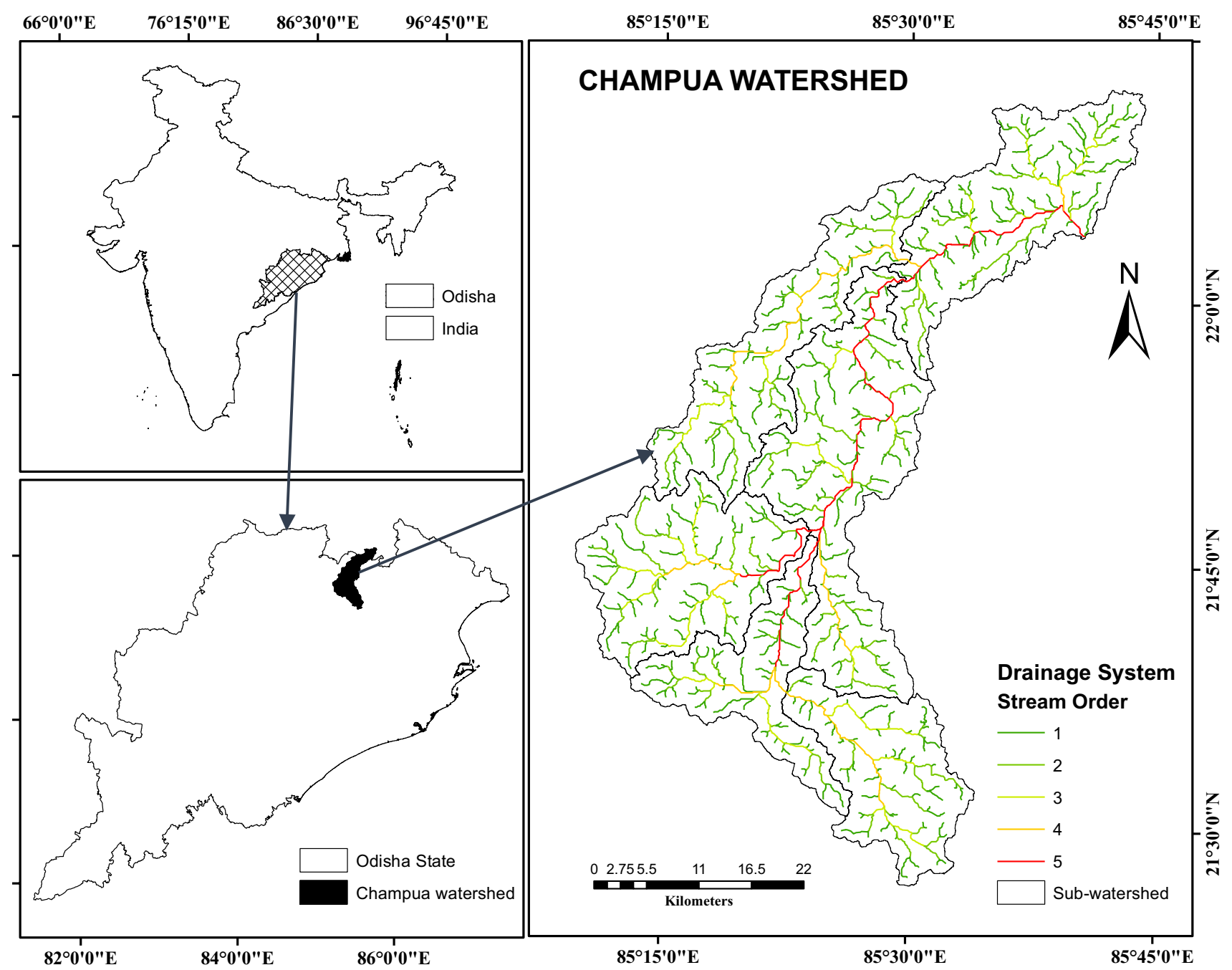

Fig. 1 Location map of the study area (Champua Watershed)

\section{Morphometric analysis}

The drainage network for each watershed has been created using the ASTER Global Digital Elevation Model (GDEM) of resolution $30 \mathrm{~m} \times 30 \mathrm{~m}$ downloaded from National Aeronautics and Space Administration (NASA) with the help of Arc Map 10.3. The computation of various parameters, viz. watershed area, watershed perimeter, stream order, stream length, number of stream, highest and lowest points of watershed have been carried out separately for each watershed. These morphometric parameters with the standard formulae are used for the determination of various other morphometric parameters such as bifurcation ratio, stream frequency, form factor, circularity ratio, elongation ratio, texture ratio, compactness coefficient, relief ratio, length of overland flow and drainage density which are given in Table 1.
The soil loss in the watershed is either proportional or inversely proportional to these parameters. For example, soil loss is proportional to bifurcation ratio, drainage density, stream frequency, texture ratio, relief ratio and length of overland flow. It is inversely proportional to circulatory ratio, form factor, elongation ratio and compactness coefficient (Biswas et al. 1999; Ratnam et al. 2005; Javed et al. 2009). Sub-watersheds are given a score for each of the parameters accordingly. The sub-watersheds which are more vulnerable to soil loss will have a higher value of the directly proportional parameter, and the rank will be lowest (say 1) and the vice versa. All the parameters are considered to be equally important. Thereafter, an average value of the rank score for each of the sub-watershed is calculated. On the basis of this, the sub-watershed with lower rank is identified as the most vulnerable to soil loss. Therefore, the sub-watershed with a lower rank score should be given top priority for soil 
Table 1 Morphometric parameters, their formula and references

\begin{tabular}{|c|c|c|c|}
\hline S. no & Morphometric parameters & Formula & References \\
\hline 1 & Stream order $(\psi)$ & Position of stream (hierarchical rank) & Strahler (1952) \\
\hline 2 & Number of streams $(N \psi)$ & $N \psi=N_{1}+N_{2}+N_{3} \ldots N_{n}$ & Horton (1945) \\
\hline 3 & Stream length $(L \psi) \mathrm{km}$ & $L \psi=L_{1}+L_{2}+L_{3} \ldots L_{n}$ & Strahler (1952) \\
\hline 4 & Mean stream length $(\overline{\mathrm{L}} \psi) \mathrm{km}$ & $\overline{\mathrm{L}} \psi=\Sigma L \psi / N \psi$ & Horton (1945) \\
\hline 5 & Bifurcation ratio $(\mathrm{Rb})$ & $R b=N \psi / N(\psi+1)$ & Schumm (1956) \\
\hline 6 & Mean bifurcation ratio (Rbm) & Average of all bifurcation ratio & Strahler (1964) \\
\hline 7 & Total basin relief $(\mathrm{H})$ & $\begin{array}{l}H=H \max -H \min , \text { where Hmax and Hmin are the highest } \\
\text { and lowest points of watershed }\end{array}$ & Strahler (1952) \\
\hline 8 & Drainage density $(\mathrm{Dd}) \mathrm{km} \mathrm{s}^{-1}$ & $\mathrm{Dd}=\Sigma L \psi / \mathrm{Ab}$ where $\mathrm{Ab}$ is the basin area & Horton (1932) \\
\hline 9 & Stream frequency $(\mathrm{Fs})$ & $\mathrm{Fs}=\Sigma N \psi / \mathrm{Ab}$ where $\mathrm{Ab}$ is the basin area & Horton (1932) \\
\hline 10 & Texture ratio $(\mathrm{Tr})$ & $\operatorname{Tr}(\psi)=N \psi / \mathrm{Pb}(\psi=1,2,3 \ldots n)$ & Schumm (1956) \\
\hline 11 & Form factor $\left(F_{\mathrm{f}}\right)$ & $F_{\mathrm{f}}=\mathrm{Ab} / \mathrm{Lb}^{2}$ where $\mathrm{Lb}$ is the basin length & Horton $(1932,45)$ \\
\hline 12 & Elongation ratio $(\mathrm{Er})$ & $\mathrm{Er}=\mathrm{Dd} / \mathrm{Lb}$ where $\mathrm{Lb}$ is the basin length & Schumm (1956) \\
\hline 13 & Circularity ratio $(\mathrm{Cr})$ & $\mathrm{Cr}=12.56 \mathrm{~A} / \mathrm{Pb}^{2}$ where $\mathrm{Pb}$ is the basin perimeter & Miller (1953), Strahler (1964) \\
\hline 14 & Compactness coefficient $(\mathrm{Cc})$ & $\mathrm{Cc}=0.2841 \times \mathrm{Pb} / \mathrm{Ab}^{0.5}$ where $\mathrm{Ab}$ is the basin area & Gravelius (1914) \\
\hline 15 & Length of overland flow (Lo) & $\mathrm{Lo}=1 / 2 \mathrm{Dd}$ & Horton (1945) \\
\hline 16 & Relief ratio $(\mathrm{Rr})$ & $\mathrm{Rr}=\mathrm{H} / \mathrm{Lb}$ where $\mathrm{Lb}$ is the basin length & Schumm (1956) \\
\hline
\end{tabular}

conservation measures. Thus, the lowest value of shape parameters was assigned as rank 1, next lower value was assigned as rank 2 and so on and the highest value was rated last in rank. Hence, the ranking of the sub-watersheds has been determined by assigning the priority/rank (Table 8). At last, the composite rank has been calculated as averaging all the parameters in particular sub-watersheds. However, the final priority has been assigned as the least rating value was assigned as the highest priority; the next higher value was assigned second priority and so on. Finally, the highest score of composite rank was assigned the last rank. The above parameters have been taken for assigning the priority of the sub-watersheds for preserving the top surface of soil which are more fertile and essential for food production.

\section{Land use/land cover (LULC) map analysis}

The LULC change analysis has requisite of the remote sensing cloud-free satellite image (Landsat 7 ETM + imagery). November 2001 and November 2011 path 140 and row 45 has been downloaded from the US Geological Survey https ://earthexplorer.usgs.gov/ Web site. Satellite imageries have been downloaded (website: https://earthexplorer.usgs.gov/) for the year 2001 and 2011 having row/ path number is 140/ 45, respectively. The unsupervised classification has been carried out for LULC change analysis by using the ERDAS IMAGINE 2014 software. The watershed and subwatersheds have been classified into seven distinct classes as fallow land, forest land, settlement, shrubs, water, agricultural land and wasteland. The LULC percentage change area detection from 2001 and 2011 has been used for prioritization of sub-watershed. Methodology used in this study is explained with the help of flowchart given in Fig. 2.

The LULC changes affect the global environment that would ultimately undermine ecosystem services, human welfare, long-term sustainability of human being (Foley et al. 2005) and also give emphases on minimizing the negative environmental impacts of land use during accomplishment of the economic and social benefits. The agricultural growth is the prime requirement of growing population in developing country; therefore, LULC changes like increase in agricultural land are beneficial for the common people. The agricultural activity depends upon water availability. This requirement can be fulfilled by surface water (river and rainfall) and groundwater. The increase in availability of water, shrubland and forestland is positive for conservation of watershed in several ways (which reduces soil erosion and flash flood, etc.) while a decrease in fallow land and wasteland is positive change. According to land feature, the rate of flow is directly proportional to the settlement, fallow land, wasteland and water and inversely proportional to shrubland, agricultural land, forest land. The lesser priority values are assigned to those LULC categories which are more deteriorated (erosion) with the passage of time (Javed et al. 2009; Iqbal and Sajjad 2014). From management point of view, the conservation practices or measures are recommended as per their final priority. 
Fig. 2 Methodology used for LULC change detection

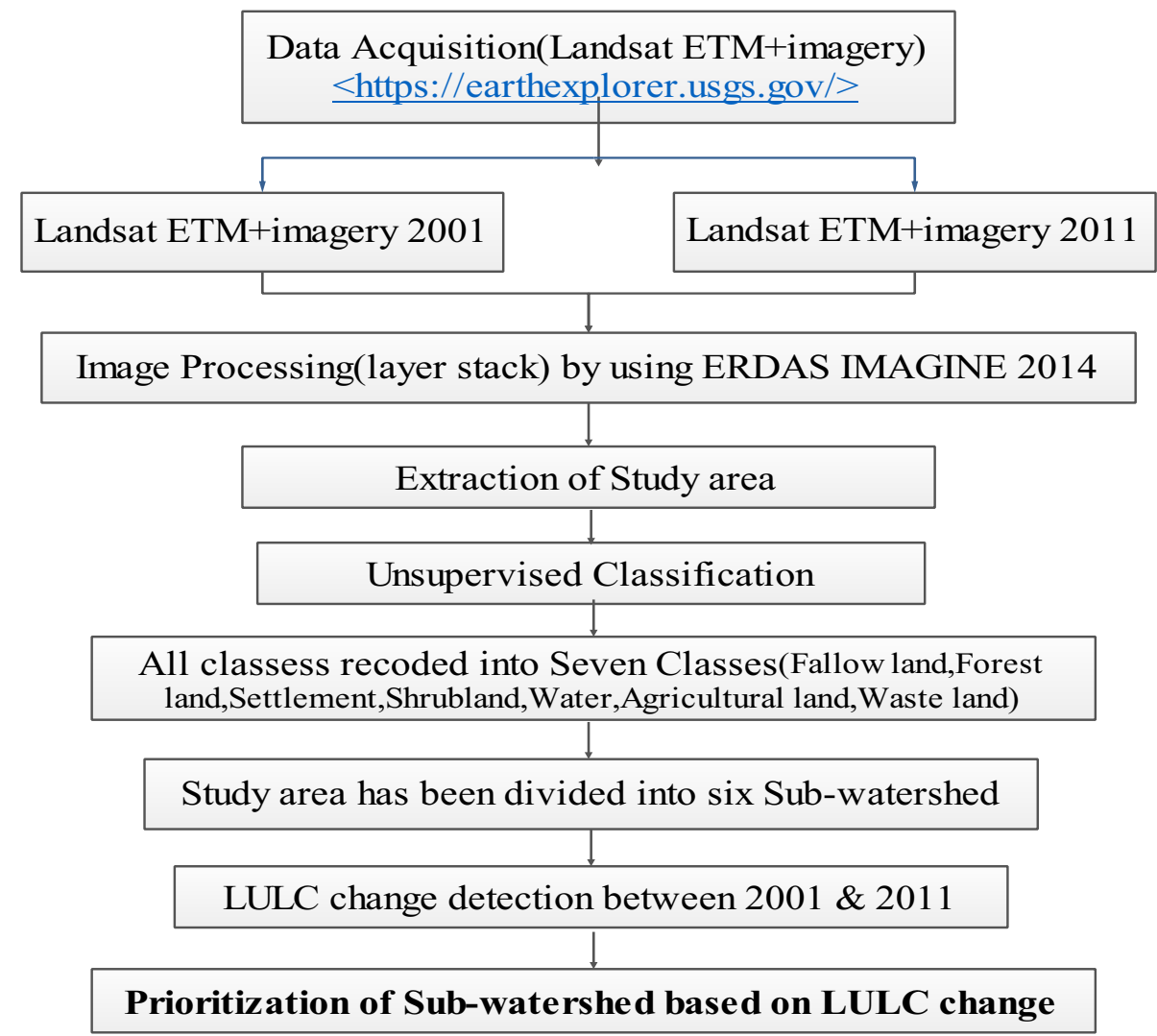

\section{Results and discussion}

\section{Morphometric analysis}

Morphometric analysis of catchment is important and used for developing the regional-scale hydrological models for solving various hydrological problems such as drought, flood and soil erosion. The various parameters which deteriorate the watershed have been worked out from respective Champua sub-watersheds (C-SWS-1, C-SWS-2, C-SWS-3, C-SWS-4, C-SWS-5 and C-SWS-6) by using the RS and GIS approach.

\section{Stream order $(\psi)$}

The estimation of stream orders is a major step for morphometric analysis, which is based on the delineated streams and their branching suggested by the author (Strahler 1964). The whole stream network consists of first, second, third, fourth and fifth stream order channels. The higher order will be formed when two channels of the same order meet. Order of stream always increases while moving toward downward in watershed geo-morphology. A perusal of Table 2 indicates that there are six sub-watersheds, out of these two sub-watersheds are fifth ordered (C-SWS-1, C-SWS-4) and remaining four
Table 2 Number of streams and stream lengths of Champua sub-watershed of Baitarani river basin

\begin{tabular}{|c|c|c|c|c|c|c|c|c|c|c|c|c|}
\hline \multirow[t]{2}{*}{ S. no. } & \multirow[t]{2}{*}{ Sub-basin name } & \multirow[t]{2}{*}{ Area $(\mathrm{Ab}) \mathrm{km}^{2}$} & \multicolumn{5}{|c|}{$\begin{array}{l}\text { No. of streams of differ- } \\
\text { ent orders }(N \psi)\end{array}$} & \multicolumn{5}{|c|}{$\begin{array}{l}\text { Stream lengths ( } \mathrm{Lb} \text { in } \mathrm{km} \text { ) of differ- } \\
\text { ent orders }\end{array}$} \\
\hline & & & I & II & III & IV & V & I & II & III & IV & V \\
\hline 1 & C-SWS-1 & 332.59 & 103 & 23 & 5 & 2 & 1 & 144.8 & 71.6 & 35.0 & 14.2 & 3.8 \\
\hline 2 & C-SWS-2 & 306.56 & 90 & 20 & 5 & 1 & & 123.4 & 51.8 & 24.3 & 33.5 & - \\
\hline 3 & C-SWS-3 & 425.79 & 135 & 31 & 6 & 2 & & 161.2 & 82.1 & 24.3 & 42.4 & - \\
\hline 4 & C-SWS-4 & 312.46 & 90 & 18 & 5 & 2 & 1 & 115.0 & 53.0 & 36.2 & 9.4 & 12.8 \\
\hline 5 & C-SWS-5 & 204.31 & 66 & 14 & 3 & 1 & & 90.0 & 26.3 & 16.2 & 24.2 & - \\
\hline 6 & C-SWS-6 & 234.04 & 66 & 16 & 3 & 1 & & 75.6 & 41.0 & 26.3 & 18.9 & - \\
\hline Total & CWS area & 1815.75 & 550 & 122 & 27 & 9 & 2 & 710.0 & 325.9 & 162.3 & 142.7 & 16.6 \\
\hline
\end{tabular}


are fourth ordered (C-SWS-2, C-SWS-3, C-SWS-5 and C-SWS-6) and there is no third-ordered sub-watershed. Bifurcation ratio depends on stream order as well as a number of streams. Total number of streams and stream length of all orders are 710 and $1357.5 \mathrm{~km}$, respectively. The Champua sub-watershed wise (C-SWS-1, C-SWS-2, C-SWS-3, C-SWS-4, C-SWS-5 and C-SWS-6) of stream order and a digital elevation map are shown in Fig. 3.

\section{Stream length $(L \psi)$}

Horton's second law (1945) states that the stream length of the different sub-basins validates the "law of stream lengths," and this law is exemplified by plotting the graph of stream number and average stream length (on logarithmic scale) against stream order (on arithmetic scale). The plotted point forms approximately a straight line. This linear connection with little deviation in a straight line is found in most of drainage networks (Chow 1964). Generally, the total length of stream segments decreases with increase in stream order. The stream length and total stream length are shown in Tables 2 and 3, respectively.

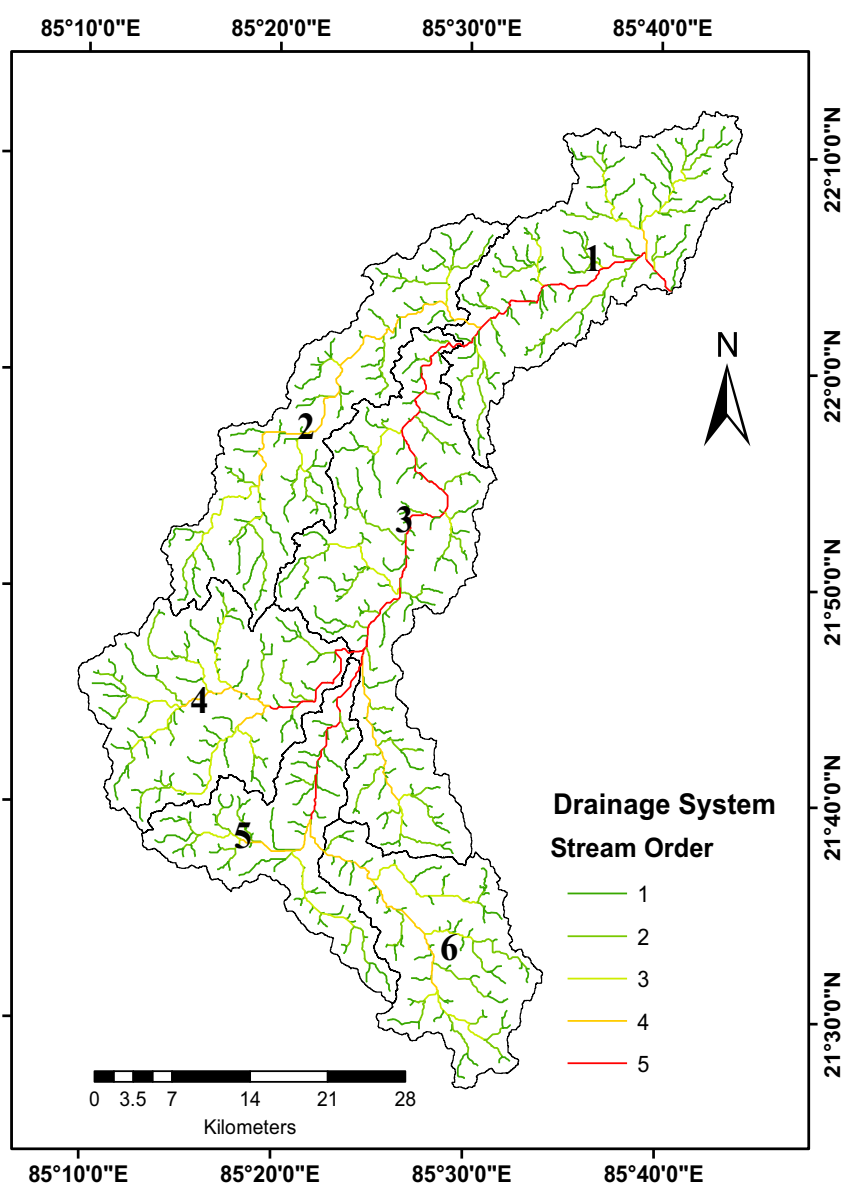

\section{Bifurcation ratio $(\mathbf{R b})$}

The bifurcation ratio $(\mathrm{Rb})$ represents the geological as well as tectonic characteristics of the watershed (Gajbhiye et al. 2014). The bifurcation ratio is dimensionless parameter whose values range from 3.0 to 5.0. The potential of flood damage increases with the increases in values of $\mathrm{Rb}(\mathrm{McCul}-$ lagh, 1978). Lower value ( $\mathrm{Rb})$ indicates the partially disturbed watershed without any distortion in the drainage pattern (Nag 1998). The high value of Rb indicates the severe overland flow (more soil erosion) and low recharge for the sub-watershed. In this study, the value of the mean Rb lies between 3.28 and 4.50 which is shown in Table 4 .

\section{Drainage density (Dd)}

Drainage density (Dd) is another important parameter and depends upon the function of climate, lithology and structure characteristics of the drainage basins. The higher values of drainage density reflect higher dissected drainage watershed and rapid response with respect to rainfall events and for lower values vice versa. It is a basic length scale

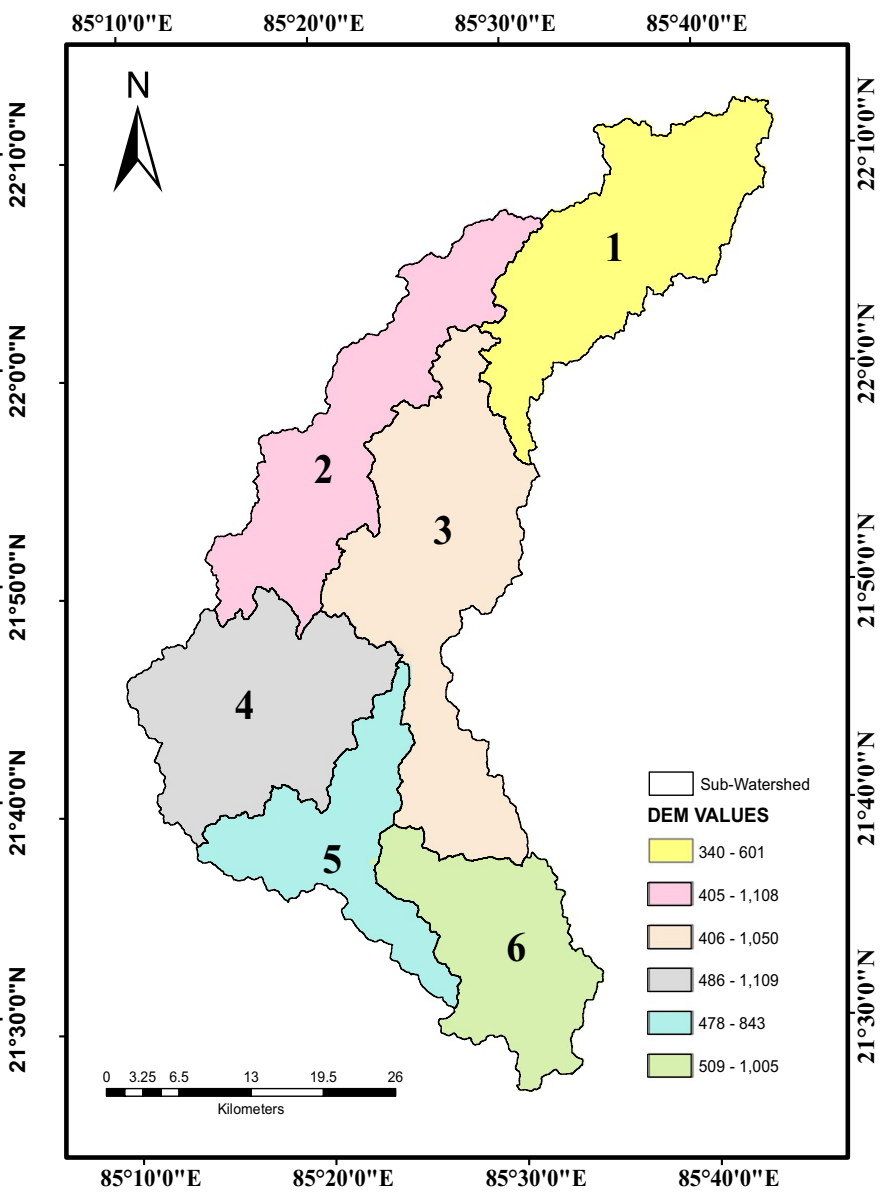

Fig. 3 Watershed characteristics. a Stream order of sub-watersheds. b Digital elevation map of the sub-watershed 
Table 3 Various morphometric parameters of Champua sub-watershed for Baitarani River

\begin{tabular}{|c|c|c|c|c|c|c|c|c|}
\hline \multirow[t]{2}{*}{ Sub-basin name } & \multirow[t]{2}{*}{ Area $(\mathrm{Ab}) \mathrm{km}^{2}$} & \multirow[t]{2}{*}{ Perimeter $(\mathrm{Pb}) \mathrm{km}$} & \multicolumn{2}{|c|}{ Elevation $\mathrm{m}$} & \multirow{2}{*}{$\begin{array}{l}\text { Basin length } \\
\text { (Lb) km }\end{array}$} & \multirow{2}{*}{$\begin{array}{l}\text { Total relief } \\
\text { (H) } \mathrm{m}\end{array}$} & \multirow{2}{*}{$\begin{array}{l}\text { Number of } \\
\text { streams }(N \psi)\end{array}$} & \multirow{2}{*}{$\begin{array}{l}\text { Total stream } \\
\text { length }(L \psi)\end{array}$} \\
\hline & & & Hmax & Hmin & & & & \\
\hline C-SWS-1 & 332.59 & 165.60 & 601 & 340 & 35.56 & 261 & 134 & 270 \\
\hline C-SWS-2 & 306.56 & 187.00 & 1108 & 405 & 45.11 & 703 & 116 & 233 \\
\hline C-SWS-3 & 425.79 & 206.52 & 1050 & 406 & 46.31 & 644 & 174 & 310 \\
\hline C-SWS-4 & 312.46 & 132.00 & 1109 & 486 & 25.8 & 623 & 116 & 226 \\
\hline C-SWS-5 & 204.31 & 201.31 & 843 & 478 & 20.61 & 365 & 84 & 157 \\
\hline C-SWS-6 & 234.04 & 114.42 & 1005 & 509 & 26.81 & 496 & 86 & 162 \\
\hline
\end{tabular}

Table 4 Additional morphometric parameters of Champua sub-watershed for Baitarani River

\begin{tabular}{lllllllllll}
\hline Basin name & $\mathrm{Rb}$ & $\mathrm{Dd}$ & $\mathrm{Fs}$ & $\mathrm{Cr}$ & $F_{\mathrm{f}}$ & $\mathrm{Er}$ & $\mathrm{Tr}$ & $\mathrm{Cc}$ & $\mathrm{Rr}$ & Lo \\
\hline C-SWS-1 & 3.39 & 0.81 & 0.40 & 0.15 & 0.26 & 0.58 & 0.81 & 2.56 & 7.34 & 0.40 \\
C-SWS-2 & 4.50 & 0.76 & 0.38 & 0.11 & 0.15 & 0.44 & 0.62 & 3.01 & 15.58 & 0.38 \\
C-SWS-3 & 4.17 & 0.73 & 0.41 & 0.13 & 0.20 & 0.50 & 0.84 & 2.82 & 13.91 & 0.36 \\
C-SWS-4 & 3.28 & 0.72 & 0.37 & 0.23 & 0.47 & 0.77 & 0.88 & 2.11 & 24.15 & 0.34 \\
C-SWS-5 & 4.13 & 0.77 & 0.41 & 0.06 & 0.25 & 0.56 & 0.42 & 3.97 & 12.76 & 0.38 \\
C-SWS-6 & 4.15 & 0.69 & 0.37 & 0.22 & 0.33 & 0.64 & 0.75 & 2.11 & 18.50 & 0.35 \\
\hline
\end{tabular}

in the landscape, which is recognized to be the transition point between scales where unstable channel-forming processes yield stable diffusive processes (Tarboton et al. 1992). Drainage density is influenced by various factors, among which resistance to erosion of rocks, infiltration capacity of the land and climatic conditions rank high (Verstappen 1983). According to Langbein (1947), the drainage density helps to calculate the travel time of water through the basin and suggested the values ranges from 0.55 to $2.09 \mathrm{~km} / \mathrm{km}^{2}$ for humid regions. The Dd of sub-watersheds ranges from 0.69 to $0.81 \mathrm{~km} / \mathrm{km}^{2}$ which is shown in Table 4 .

\section{Stream frequency (Fs)}

Drainage frequency has close correlation with drainage density for all sub-catchments and indicates the increase in stream flow with respect to increase in drainage density (Gajbhiye et al. 2014). Stream frequency is directly proportional to soil erosion due to more surface area has been covered which produced maximum soil loss and reduces the agricultural production due to threat. Drainage frequency or channel frequency is directly related to stream population per unit area of the watershed (Horton 1932). It indicates the close correlation with drainage density value of the subwatershed. Higher value of drainage frequency shows the higher runoff (more soil erosion). In this study, C-SWS-5 and C-SWS-3 produced more runoff as compared to other sub-watersheds; however, ranges vary from 0.37 (C-SWS4, C-SWS-6) to 0.41 (C-SWS-5, C-SWS-3) as shown in Table 4.

\section{Circularity ratio $(\mathrm{Cr})$}

Circulatory ratio is influenced by the stream length, stream frequency, geological land condition, land use land/cover (LULC), climatic variability, relief and slope of the subwatersheds (Patel et al. 2013). In this present study, circularity ratio varies from 0.06 (C-SWS-5) to 0.23 (C-SWS-4). The drainage system seems to be more influenced by structural disturbance (more soil erosion) in case of lower values of circularity ratio.

\section{Form factor $\left(F_{f}\right)$}

Most of the researchers (Rekha et al. 2011; Gajbhiye et al. 2014) have suggested that the value of form factor $\left(F_{\mathrm{f}}\right)$ is less than 0.79 for perfectly circular basin. In a watershed, the smaller value of the form factor shows maximum elongation of the basin. The high value of form factor shows high peak of hydrograph in short duration and vice versa. The values of form factor for sub-watersheds vary from 0.15 to 0.47 and are given in Table 4. The SWS-2 is more elongated as compared to SWS-5 due to smaller form factor. Thus, it would generate lower peak and broader base of hydrograph. Managing flood flow is easier in elongated watershed than the circular watershed.

\section{Elongation ratio (Er)}

Elongation ratio (Er) values generally lie between 0.4 and 1.0 which is allied with an extensive variation in climate and geological properties. The values close to 1.0 represent the 
regions of very low relief, while the values in between 0.6 and 0.8 are followed with higher relief and steeper ground slope (Strahler 1964). Therefore, the values obtained can be classified into various groups, namely circular (0.9-1.0), oval (0.8-0.9), less elongated (0.7-0.8), more elongated $(0-0.5)$. In this watershed, elongation ratio varies between 0.44 (C-SWS-2) and 0.77 (C-SWS-5), whereas the feature of watershed lies oval cum elongated in nature. However, sub-watersheds are elongated with steeper slope with high relief (Chopra et al. 2005; Gajbhiye et al. 2014).

\section{Texture ratio (Tr)}

In general, the smaller values of texture ratio $(\mathrm{Tr})$ show the basin is plain with less variation in the slopes. Texture ratio depends upon properties of the lithology of the basin, infiltration of the soil and relief aspect of the terrain (Vijith and Satheesh 2006). In the study area, the texture ratio of the sub-watersheds lies between 0.42 (C-SWS-5) and 0.88 (C-SWS-4) and is categorized as medium in nature. In general, the smaller values of texture ratio show that the basin is plain with less variation in the slopes. The values of texture ratio of each sub-watershed are shown in Table 4.

\section{Compactness coefficient (Cc)}

Compactness coefficient $(\mathrm{Cc})$ term is used to express the relationship between the hydrological basin and circular basin having same area. The drainage will yield the shortest time of concentration before the peak flow occurrence is more hazardous in the case of the circular basin (Ratnam et al. 2005; Javed et al. 2009). The less value compactness coefficient is more prone to erosion. The highest values were found in C-SWS-5 (3.97), while the lowest value was for C-SWS-4 and C-SWS-6 (2.11). However, wide variations in compactness coefficient across the sub-watersheds are summarized in Table 4.

\section{Relief ratio $(\mathbf{R r})$}

In general, the relief ratio ( $\mathrm{Rr}$ ) indicates the overall slope of watershed surface. It has been seen that the higher values of $\mathrm{Rr}$ show the steepness of the basin (Vittala et al. 2004). In steep basins, the runoff due to rainfall is higher, which shows higher possibility of erosion. The values of relief ratio are given in Table 4 which range from 7.34 (C-SWS-1) to 24.15 (C-SWS-4).

\section{Length of overland flow (Lo)}

The length of overland flow (Lo) is the length of water flow over the surface of ground before it confines into definite stream channels and is approximately equal to half reciprocal of drainage density (Horton, 1945). This factor (Lo) is inversely proportional to the average channel slope and is quite synonymous with the length of sheet flow. The values of the length of overland flow in sub-watersheds vary from 0.34 (C-SWS-4) to $0.40 \mathrm{~km}$ (C-SWS-1).

\section{Land use/land cover analysis}

The rapidly increasing population is a major issue which has often led to land use and land cover (LULC) in terms of deforestation, settlement, agriculture, industrialization, etc. This demand has put tremendous pressure on the land. If the present need is fulfilled in unplanned manner, it will deteriorate the watershed. Therefore, the systematic management of LULC can sustain the healthy condition on the watershed. Also, It can reduce the risk of two extreme events like drought and flood. The systematic management is possible by using remote sensing (RS) technique for conserving the watershed. These techniques would reduce the cost as well as time for the analysis of the watershed.

\section{LULC changes in whole watershed}

The images of years 2001 and 2011 have been classified into seven important land features, i.e., fallow land $\left(\mathrm{F}_{\mathrm{a}} \mathrm{L}\right)$, forestland $\left(\mathrm{F}_{\mathrm{o}} \mathrm{L}\right)$, settlement $\left(\mathrm{S}_{\mathrm{e}} \mathrm{L}\right)$, shrubland $\left(\mathrm{S}_{\mathrm{h}} \mathrm{L}\right)$, water $\left(\mathrm{W}_{\mathrm{a}} \mathrm{L}\right)$, agricultural land $\left(\mathrm{A}_{\mathrm{g}} \mathrm{L}\right)$ and wasteland $\left(\mathrm{W}_{\mathrm{a}} \mathrm{L}\right)$. The derived LULC map is shown in Fig. 4. The study of Champua reveals that watershed as a whole shows considerable changes from period 2001-2011, indicating the degradation of land and other resources. These changes in land feature on watershed would change the runoff generation due to rainfall. The runoff generation generally depends upon the topography of land and land features. The rate of soil erosion is directly proportional to the runoff. Therefore, the severity of soil erosion varies according to the variation in runoff. According to land feature, the rate of flow is directly proportional to the settlement, fallow land, wasteland and water and inversely proportional to shrubland, agricultural land, forestland. It was found that the following land features reduce like forest land about $4.53 \%$, fallow land about $1.68 \%$, shrubland about $2.15 \%$, wasteland about $0.04 \%$ while some land features increase like settlement about $0.91 \%$, surface water about $0.09 \%$, agricultural land about $7.40 \%$. The detailed descriptions of LULC changes for the whole watershed are given in Table 5.

The changes in whole watershed have been examined with the help of the observed data of rainfall, runoff and sediment load, and significant variation is found in all the data due to LULC. The source of rainfall data from the Indian Metrological Department (IMD), Pune, runoff and sediment load data of Champua watershed at outlet point was procured 

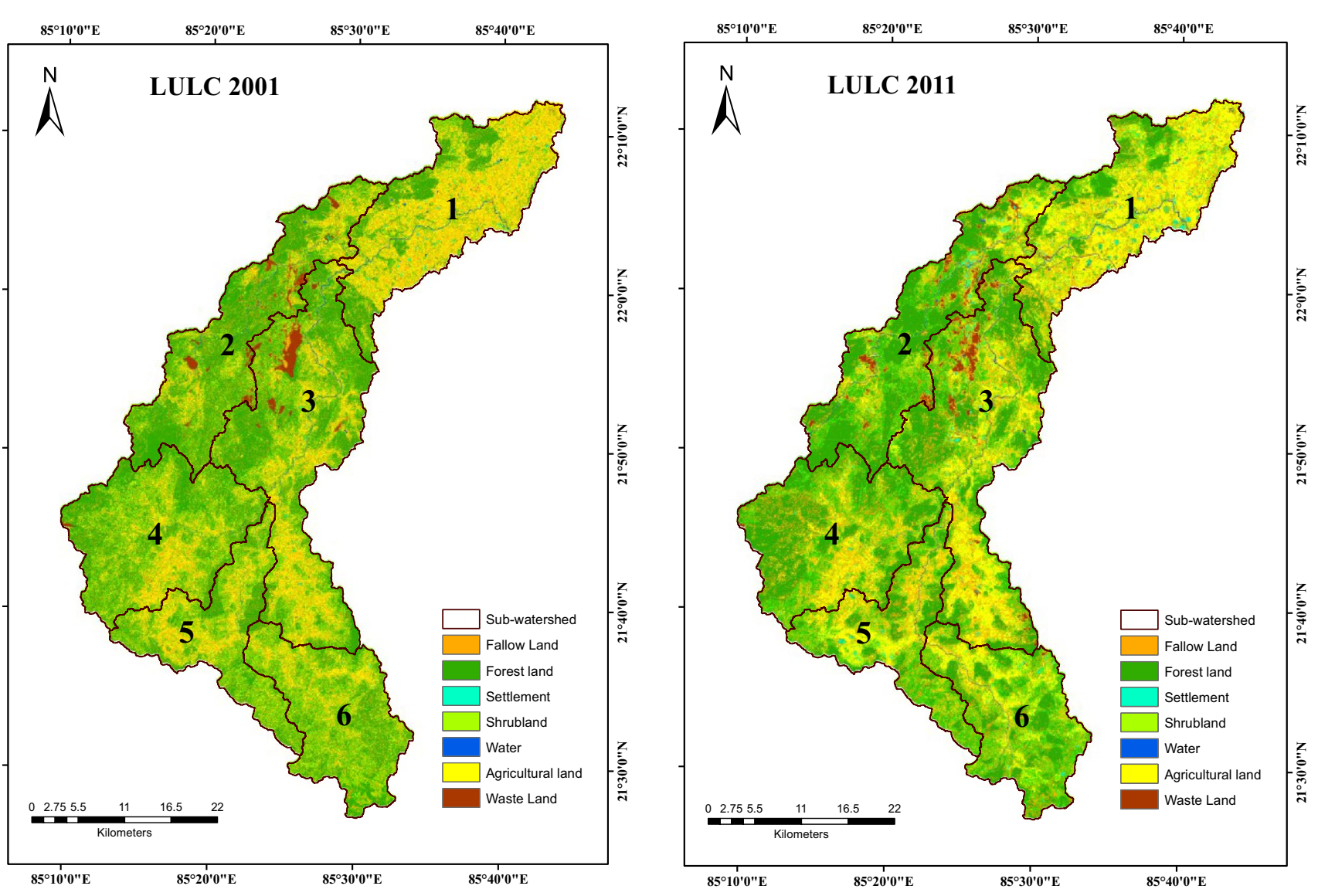

Fig. 4 LULC (2001) and LULC (2011) maps of Champua watershed for Baitarani River

Table 5 LULC change analysis from 2001 to 2011 for the whole Champua watershed

\begin{tabular}{|c|c|c|c|c|c|c|}
\hline \multirow{2}{*}{$\begin{array}{l}\text { LULC category } \\
\text { Whole watershed }\end{array}$} & \multicolumn{4}{|c|}{$\begin{array}{l}\text { Whole watershedwise LULC change area (2001 and } \\
\text { 2011) }\end{array}$} & \multicolumn{2}{|c|}{$\begin{array}{l}\text { LULC change analysis } \\
(2001-2011)\end{array}$} \\
\hline & $2001\left(\mathrm{~km}^{2}\right)$ & $2001(\%)$ & $2011\left(\mathrm{~km}^{2}\right)$ & $2011(\%)$ & Change $\left(\mathrm{km}^{2}\right)$ & Change (\%) \\
\hline Settlement & 9.75 & 0.54 & 26.30 & 1.45 & 16.55 & 0.91 \\
\hline Fallow land $\left(\mathrm{F}_{\mathrm{a}} \mathrm{L}\right)$ & 369.17 & 20.34 & 338.70 & 18.66 & -30.47 & -1.68 \\
\hline Wasteland & 28.89 & 1.59 & 28.17 & 1.54 & -0.73 & -0.04 \\
\hline Water & 10.54 & 0.58 & 12.19 & 0.67 & 1.65 & 0.09 \\
\hline Shrubland $^{\mathrm{a}}$ & 293.95 & 16.20 & 254.94 & 14.05 & -39.02 & -2.15 \\
\hline Agricultural land ${ }^{\mathrm{a}}$ & 274.80 & 15.14 & 409.11 & 22.54 & 134.31 & 7.40 \\
\hline Forestland $^{\mathrm{a}}$ & 827.89 & 45.61 & 745.60 & 41.08 & -82.29 & -4.53 \\
\hline Total & 1815.00 & 100 & 1815 & 100 & No change & No change \\
\hline
\end{tabular}

${ }^{a}$ Shows the inversely proportional relationship with the runoff from the Web site (http://www.india-wris.nrsc.gov.in). The monthly rainfall $(\mathrm{mm})$, runoff (cumecs) and sediment load $(\mathrm{g} / \mathrm{l})$ trends used for analysis of the area are shown in Fig. 5.

It is observed that the peaks of the runoff and sediment load follow more or less rainfall trend. The rate of soil erosion is directly proportional to the runoff. Therefore, the severity of soil erosion varies according to the variation in runoff. According to land feature, the rate of flow is directly proportional to the settlement, fallow land, wasteland, water and inversely proportional to shrubland, agricultural land, forestland. The variation in annual maximum monthly rainfall, runoff and sediment load is given in Table 6. It is seen from the table that in comparison of rainfall 2001 with 2011, rainfall magnitude is increased by $35.62 \%$. However, the runoff magnitude is increased by $178.83 \%$. This indicates a drastic change in LULC of 


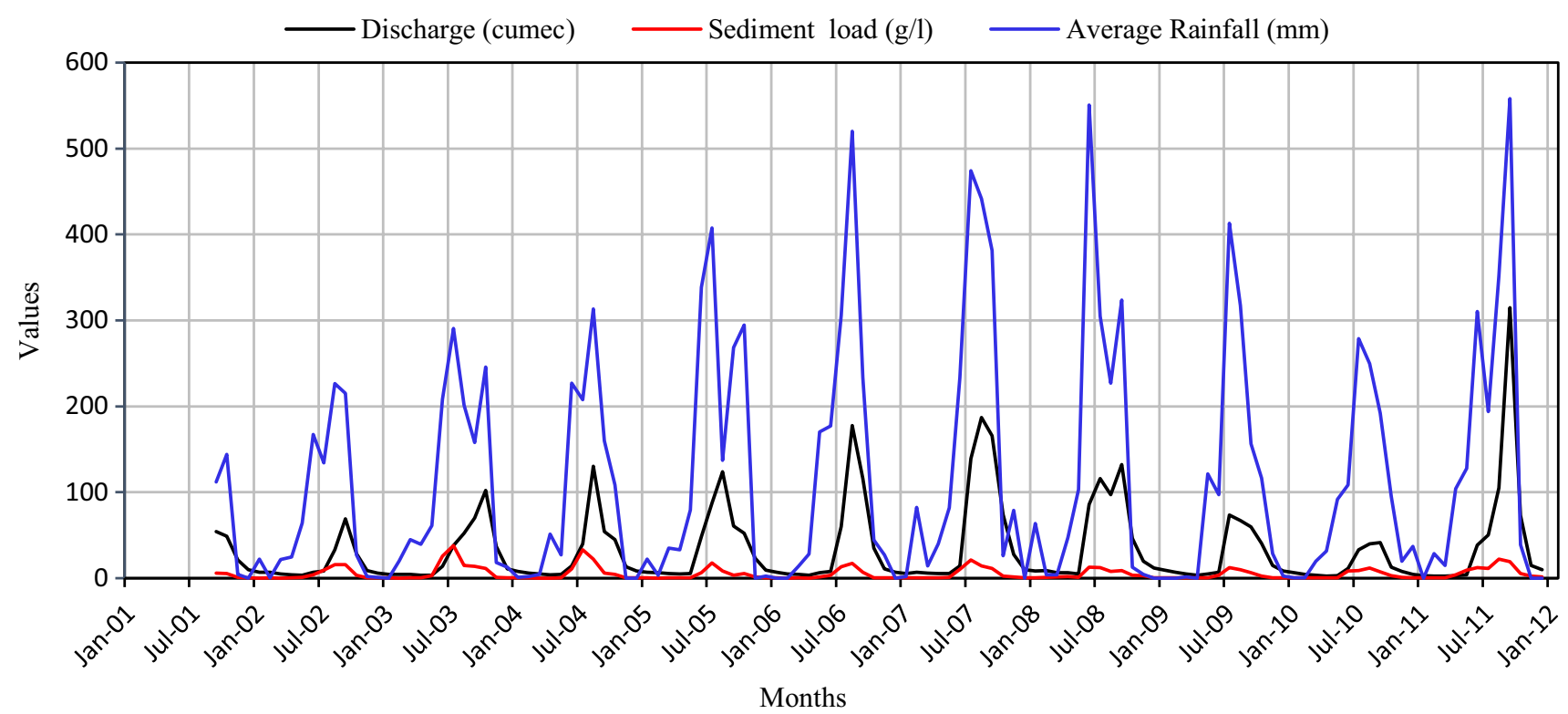

Fig. 5 Variation in monthly rainfall, discharge and sediment load of Champua watershed

Table 6 Effect on runoff and sediment amount due to change in LULC from the year 2001 to 2011

\begin{tabular}{lllr}
\hline Observed data & \multicolumn{2}{l}{$\begin{array}{l}\text { Watershedwise variation in values of various } \\
\text { data (2001 and 2011) }\end{array}$} & \multirow{2}{*}{ \% Changes } \\
\cline { 2 - 3 } & 2001 (values) & 2011 (values) & \\
\hline Max monthly rainfall (mm) & 411.47 & 558.17 & 35.62 \\
Max monthly discharge (cumecs) & 112.95 & 314.94 & 178.83 \\
Max monthly sediment load (g/l) & 16.08 & 22.4 & 39.30 \\
\hline
\end{tabular}

the area. Accordingly, increase in sediment load is also observed due to changes in LULC.

The above conclusion in the whole watershed leads to identification of changes in LULC in different sub-watersheds so that the land management of sub-watershed could be identified for the prioritization of sub-watershed.

\section{LULC changes in sub-watershed}

The whole classified image (2001 and 2011) of watershed has been divided into six sub-watersheds: C-SWS1, C-SWS2, C-SWS3, C-SWS4, C-SWS5 and C-SWS6, for macrolevel study as shown in Figs. 6 and 7.

Each watershed has seven distinct LULC classes, i.e., fallow land $\left(\mathrm{F}_{\mathrm{a}} \mathrm{L}\right)$, forestland $\left(\mathrm{F}_{\mathrm{o}} \mathrm{L}\right)$, settlement $\left(\mathrm{S}_{\mathrm{e}} \mathrm{L}\right)$, shrubland $\left(\mathrm{S}_{\mathrm{h}} \mathrm{L}\right)$, water $\left(\mathrm{W}_{\mathrm{a}} \mathrm{L}\right)$, agricultural land $\left(\mathrm{A}_{\mathrm{g}} \mathrm{L}\right)$ and wasteland $\left(\mathrm{W}_{\mathrm{a}} \mathrm{L}\right)$, and their positive and negative LULC changes have been analyzed for preserving land resources on the watershed. The details of LULC category and their changes in kilometers as well as in percentages for each watershed are shown in Table 7.

\section{Prioritization of sub-watersheds based on the morphometric parameters}

Drainage pattern of watershed refers to geospatial relationships among the streams or rivers and is associated with slope, soil type, rock resistance, structural and geological status of the basin. The study emphasizes the prioritization of the sub-watersheds on the basis of morphometric analysis. The final priority of entire six sub-watersheds and their ranking are shown in Table 8 . The maximum and minimum prioritized scores of the sub-watersheds are 2.8 and 4.3, respectively.

The sub-watersheds have been categorized into three classes as lowest (composite rank $>4$ ), medium (composite rank $=3-4$ ) and highest (composite rank $<3$ ) priority. On the basis of categories defined, the sub-watersheds, viz. SWS-2 and SWS-3, come under the highest priority, SWS-1 and SWS-5 are in medium priority and SWS-4 and SWS-6 are in the lowest priority (Table 8). Thus, the conservation practices or measures are adopted in SWS-2 and SWS-3. To archive for management point of view, the conservation 

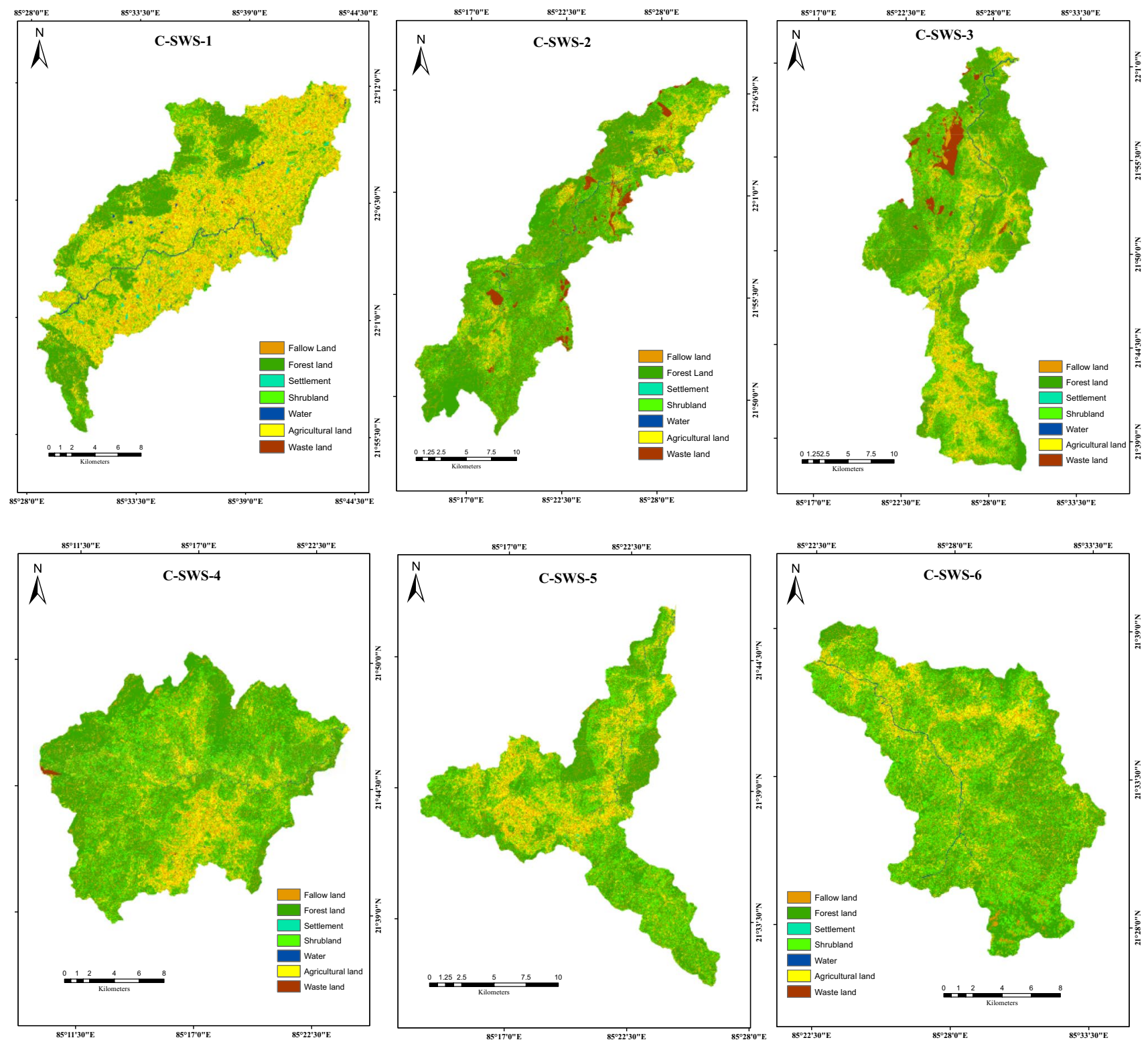

Fig. 6 LULC maps of six sub-watersheds of Champua watershed for the year 2001

practices or measures are recommended as per their final priority.

\section{Prioritization of sub-watersheds based on the LULC category}

The important land features such as fallow land $\left(\mathrm{F}_{a} \mathrm{~L}\right)$, forestland $\left(\mathrm{F}_{\mathrm{o}} \mathrm{L}\right)$, settlement $\left(\mathrm{S}_{\mathrm{e}} \mathrm{L}\right)$, shrubland $\left(\mathrm{S}_{\mathrm{h}} \mathrm{L}\right)$, water $\left(\mathrm{W}_{\mathrm{a}} \mathrm{L}\right)$, agricultural land $\left(\mathrm{A}_{\mathrm{g}} \mathrm{L}\right)$ and wasteland $\left(\mathrm{W}_{\mathrm{a}} \mathrm{L}\right)$ have been used for prioritization of subwatershed. The LULC percentage change area detection from 2001 and 2011 is given in Table 7. It is found that the forest area reduces
8.08 percent more severe and therefore was assigned Priority 1 . The sub-watersheds have been categorized into three classes as highest $(<3.5)$, medium (3.5-3.9) and lowest ( $>4.0$ ) priorities on the basis of the span of composite rank value. To archive on the basis of LULC change analysis, SWS-3, SWS-5 and SWS-6 fall in the highest priority, SWS-1 and SWS- 2 fall in medium priority and SWS-4 fall in the lowest priority category (Table 8 ). To archive for management point of view, the conservation practices or measures are recommended as per their final priority. 

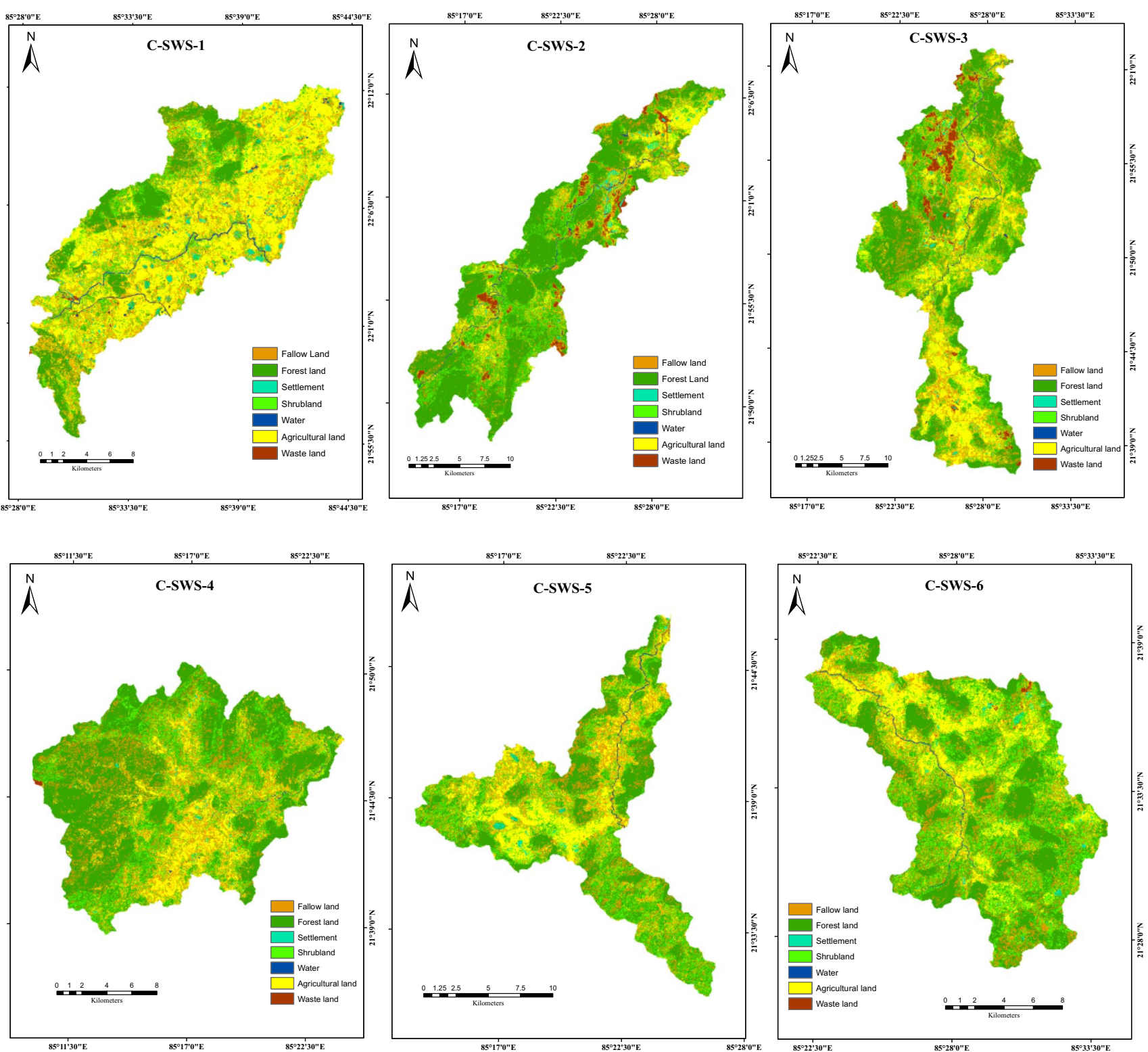

Fig. 7 LULC maps of six sub-watersheds of Champua watershed for the year 2011

\section{Discussion}

The anthropological activities on any watershed cause adverse change that ultimately deteriorates watershed. The two types of analysis such as morphometric analysis and LULC percentage changes are used for the conservation of watershed. The various morphometric parameters and LULC percentage changes are found out according to the surface topographic features of Champua subwatershed. The water availability and soil erosion have been affected due to variation in rainfall and runoff as seen in LULC change with time. LULC information derived from the satellite imaginaries and their integration with GIS can be useful for estimation of runoff, infiltration, evaporation, soil erosion and sediment yield. There are considerable changes due to huge urban expansion and development activities as observed over Champua sub-watersheds. The results obtained from both the analysis are common for sub-watersheds according to assigned priority in terms of soil erosion. Sub-watershed (C-SWS 3) has been assigned the highest priority. Thus, both analyses together can be more useful and reliable to preserve and sustain resource that ultimately affects the hydrological balance and erosion over the watershed. Therefore, morphometric and land use and land cover analysis can play a vital role in finding out the characteristics of the watershed. 
Table 7 Sub-watershedwise LULC change from the year 2001 to 2011 of the Champua watershed

\begin{tabular}{|c|c|c|c|c|c|c|}
\hline LULC Category & $2001\left(\mathrm{~km}^{2}\right)$ & $2001(\%)$ & $2011\left(\mathrm{~km}^{2}\right)$ & $2011(\%)$ & Change $\left(\mathrm{km}^{2}\right)$ & Change $(\%)$ \\
\hline \multicolumn{7}{|c|}{ Sub-watershed: C-SWS-1 } \\
\hline Settlement & 3.24 & 0.97 & 9.59 & 2.88 & 6.35 & 1.91 \\
\hline Fallow land & 91.99 & 27.66 & 60.36 & 18.15 & -31.62 & -9.51 \\
\hline Wasteland & 1.14 & 0.34 & 1.19 & 0.36 & 0.05 & 0.02 \\
\hline Water & 3.10 & 0.93 & 3.92 & 1.18 & 0.81 & 0.24 \\
\hline Shrubland & 27.40 & 8.24 & 27.21 & 8.18 & -0.19 & -0.06 \\
\hline Agricultural land & 111.55 & 33.54 & 155.21 & 46.67 & 43.66 & 13.13 \\
\hline Forestland & 94.17 & 28.31 & 75.11 & 22.58 & -19.06 & -5.73 \\
\hline Total & 332.59 & 100 & 332.59 & 100 & No change & No change \\
\hline \multicolumn{7}{|c|}{ Sub-watershed: $C-S W S-2$} \\
\hline Settlement & 1.24 & 0.41 & 4.61 & 1.50 & 3.37 & 1.10 \\
\hline Fallow land & 51.79 & 16.89 & 43.45 & 14.18 & -8.33 & -2.72 \\
\hline Wasteland & 12.06 & 3.94 & 11.52 & 3.76 & -0.55 & -0.18 \\
\hline Water & 1.84 & 0.60 & 2.81 & 0.92 & 0.98 & 0.32 \\
\hline Shrubland & 38.06 & 12.42 & 44.45 & 14.50 & 6.39 & 2.08 \\
\hline Agricultural land & 23.80 & 7.77 & 30.30 & 9.88 & 6.49 & 2.12 \\
\hline Forestland & 177.77 & 57.99 & 169.41 & 55.26 & -8.35 & -2.72 \\
\hline Total & 306.56 & 100 & 306.56 & 100 & No change & No change \\
\hline \multicolumn{7}{|c|}{ Sub-watershed: $C-S W S-3$} \\
\hline Settlement & 2.43 & 0.57 & 5.17 & 1.21 & 2.74 & 0.64 \\
\hline Fallow land & 84.27 & 19.79 & 86.18 & 20.24 & 1.91 & 0.45 \\
\hline Wasteland & 14.38 & 3.38 & 14.54 & 3.42 & 0.16 & 0.04 \\
\hline Water & 2.94 & 0.69 & 2.85 & 0.67 & -0.09 & -0.02 \\
\hline Shrubland & 67.18 & 15.78 & 57.14 & 13.42 & -10.03 & -2.36 \\
\hline Agricultural land & 56.70 & 13.32 & 96.40 & 22.64 & 39.70 & 9.32 \\
\hline Forestland & 197.90 & 46.48 & 163.50 & 38.40 & -34.39 & -8.08 \\
\hline Total & 425.79 & 100 & 425.79 & 100 & No change & No change \\
\hline \multicolumn{7}{|c|}{ Sub-watershed: $C-S W S-4$} \\
\hline Settlement & 0.92 & 0.29 & 2.00 & 0.64 & 1.09 & 0.35 \\
\hline Fallow land & 57.15 & 18.29 & 65.00 & 20.80 & 7.85 & 2.51 \\
\hline Wasteland & 0.95 & 0.30 & 0.32 & 0.10 & -0.62 & -0.20 \\
\hline Water & 0.70 & 0.22 & 0.56 & 0.18 & -0.14 & -0.04 \\
\hline Shrubland & 61.81 & 19.78 & 41.03 & 13.13 & -20.77 & -6.65 \\
\hline Agricultural land & 30.46 & 9.75 & 41.24 & 13.20 & 10.78 & 3.45 \\
\hline Forestland & 160.48 & 51.36 & 162.29 & 51.94 & 1.82 & 0.58 \\
\hline Total & 312.46 & 100 & 312.46 & 100 & No change & No change \\
\hline \multicolumn{7}{|c|}{ Sub-watershed: $C-S W S-5$} \\
\hline Settlement & 0.98 & 0.48 & 2.64 & 1.29 & 1.66 & 0.81 \\
\hline Fallow land & 42.24 & 20.68 & 43.50 & 21.29 & 1.26 & 0.62 \\
\hline Wasteland & 0.19 & 0.09 & 0.13 & 0.06 & -0.06 & -0.03 \\
\hline Water & 0.98 & 0.48 & 1.00 & 0.49 & 0.02 & 0.01 \\
\hline Shrubland & 43.42 & 21.25 & 36.46 & 17.84 & -6.97 & -3.41 \\
\hline Agricultural land & 28.80 & 14.10 & 42.83 & 20.96 & 14.02 & 6.86 \\
\hline Forestland & 87.69 & 42.92 & 77.74 & 38.05 & -9.94 & -4.87 \\
\hline Total & 204.31 & 100 & 204.31 & 100 & No change & No change \\
\hline \multicolumn{7}{|c|}{ Sub-watershed: $C-S W S-6$} \\
\hline Settlement & 0.98 & 0.42 & 2.30 & 0.98 & 1.32 & 0.56 \\
\hline Fallow land & 42.04 & 17.96 & 40.33 & 17.23 & -1.70 & -0.73 \\
\hline Wasteland & 0.19 & 0.08 & 0.47 & 0.20 & 0.29 & 0.12 \\
\hline Water & 0.94 & 0.40 & 1.04 & 0.45 & 0.11 & 0.05 \\
\hline Shrubland & 56.16 & 23.99 & 48.75 & 20.83 & -7.41 & -3.17 \\
\hline
\end{tabular}


Table 7 (continued)

\begin{tabular}{lclllll}
\hline LULC Category & $2001\left(\mathrm{~km}^{2}\right)$ & $2001(\%)$ & $2011\left(\mathrm{~km}^{2}\right)$ & $2011(\%)$ & Change $\left(\mathrm{km}^{2}\right)$ & Change (\%) \\
\hline Agricultural land & 23.61 & 10.09 & 43.30 & 18.50 & 19.69 & 8.41 \\
Forestland & 110.14 & 47.06 & 97.84 & 41.81 & -12.29 & -5.25 \\
Total & 234.04 & 100 & 234.04 & 100 & No change & No change \\
\hline
\end{tabular}

Table 8 Prioritization of sub-watersheds (morphometric parameters and LULC category)

\begin{tabular}{|c|c|c|c|c|c|c|c|}
\hline \multirow[t]{2}{*}{ A } & \multirow[t]{2}{*}{ Morphometric parameters } & \multicolumn{6}{|c|}{ Morphometric parameter values with their priorities } \\
\hline & & C-SWS-1 & C-SWS-2 & C-SWS-3 & C-SWS-4 & C-SWS-5 & C-SWS-6 \\
\hline 1 & Mean $\mathrm{BF}$ ratio $(\mathrm{Rb})$ & $3.39(5)$ & $4.50(1)$ & $4.17(2)$ & $3.28(6)$ & $4.13(4)$ & $4.15(3)$ \\
\hline 2 & Drainage density (Dd) & $0.81(1)$ & $0.76(3)$ & $0.73(4)$ & $0.72(5)$ & $0.77(2)$ & $0.69(6)$ \\
\hline 3 & Stream frequency $(\mathrm{Fs})$ & $0.40(3)$ & $0.38(4)$ & $0.41(2)$ & $0.37(5)$ & $0.41(1)$ & $0.37(6)$ \\
\hline 4 & Circularity ratio $(\mathrm{Cr})$ & $0.15(4)$ & $0.11(2)$ & $0.13(3)$ & $0.23(6)$ & $0.06(1)$ & $0.22(5)$ \\
\hline 5 & Form factor $\left(F_{\mathrm{f}}\right)$ & $0.26(4)$ & $0.15(1)$ & $0.20(2)$ & $0.47(6)$ & $0.25(3)$ & $0.33(5)$ \\
\hline 6 & Elongation ratio (Er) & $0.58(4)$ & $0.44(1)$ & $0.50(2)$ & $0.77(6)$ & $0.56(3)$ & $0.64(5)$ \\
\hline 7 & Texture ratio $(\mathrm{Tr})$ & $0.81(3)$ & $0.62(5)$ & $0.84(2)$ & $0.88(1)$ & $0.42(6)$ & $0.75(4)$ \\
\hline 8 & Compactness $(\mathrm{Cc})$ & $2.56(3)$ & $3.01(5)$ & $2.82(4)$ & $2.11(1)$ & $3.97(6)$ & $2.11(2)$ \\
\hline 9 & Relief ratio $(\mathrm{Rr})$ & $7.34(6)$ & $15.5(3)$ & $13.9(4)$ & $24.1(1)$ & $12.7(5)$ & $18.5(2)$ \\
\hline 10 & Length of overland flow (Lo) & $0.40(1)$ & $0.38(3)$ & $0.36(4)$ & $0.34(6)$ & $0.38(2)$ & $0.35(5)$ \\
\hline Composite rank (CR) & & 3.40 & 2.80 & 2.90 & 4.30 & 3.30 & 4.30 \\
\hline Final priority (FP) & & Medium & Highest & Highest & Lowest & Medium & Lowest \\
\hline \multirow[t]{2}{*}{ B } & \multirow[t]{2}{*}{ LULC category } & \multicolumn{6}{|c|}{ LULC area change in (\%) with their priorities } \\
\hline & & C-SWS-1 & C-SWS-2 & C-SWS-3 & C-SWS-4 & C-SWS-5 & C-SWS-6 \\
\hline 1 & Settlement $\left(\mathrm{S}_{\mathrm{e}} \mathrm{L}\right)$ & $1.91(1)$ & $1.10(2)$ & $0.64(4)$ & $0.35(6)$ & $0.81(3)$ & $0.56(5)$ \\
\hline 2 & Fallow land $\left(\mathrm{F}_{\mathrm{a}} \mathrm{L}\right)$ & $-9.51(6)$ & $-2.72(5)$ & $0.45(3)$ & $2.51(1)$ & $0.62(2)$ & $-0.73(4)$ \\
\hline 3 & Wasteland $\left(\mathrm{W}_{\mathrm{a}} \mathrm{L}\right)$ & $0.02(3)$ & $-0.18(5)$ & $0.04(2)$ & $-0.20(6) 3$ & $-0.03(4)$ & $0.12(1)$ \\
\hline 4 & Water $\left(\mathrm{W}_{\mathrm{a}} \mathrm{L}\right)$ & $0.24(2)$ & $0.32(1)$ & $-0.02(5)$ & $-0.04(6)$ & $0.01(4)$ & $0.05(3)$ \\
\hline 5 & Shrubland $\left(\mathrm{S}_{\mathrm{h}} \mathrm{L}\right)$ & $-0.06(5)$ & $2.08(6)$ & $-2.36(4)$ & $-6.65(1)$ & $-3.41(2)$ & $-3.17(3)$ \\
\hline 6 & Agricultural land $\left(\mathrm{A}_{\mathrm{g}} \mathrm{L}\right)$ & $13.13(6)$ & $2.12(1)$ & $9.32(5)$ & $3.45(2)$ & $6.86(3)$ & $8.41(4)$ \\
\hline 7 & Forestland $\left(\mathrm{F}_{\mathrm{o}} \mathrm{L}\right)$ & $-5.73(2)$ & $-2.72(5)$ & $-8.08(1)$ & $0.58(6)$ & $-4.87(4)$ & $-5.25(3)$ \\
\hline Composite rank (CR) & & 3.57 & 3.57 & 3.43 & 4.00 & 3.14 & 3.29 \\
\hline Final priority (FP) & & Medium & Medium & Highest & Lowest & Highest & Highest \\
\hline
\end{tabular}

\section{Conclusion}

The various morphometric parameters are calculated which are directly and indirectly related to soil erosion. The composite ranks are calculated, and the lesser value shows more priority. The sub-watersheds C-SWS-2 and C-SWS-3 are more prone to soil erosion by morphometric analysis; thus, they should be under highest priority for conservation. The LULC change percentages over decade are calculated and according to conservation measure can be applied for the sub-watersheds. Due to LULC changes, reduction in forest, shrubs areas and increase in settlement area of sub-watersheds C-SWS-3, C-SWS-5 and C-SWS-6 should be under highest priority. C-SWS-3 is found to be more prone to soil erosion due to morphometric analysis and highest percentage changes in the areas like forest area $(-8.08)$, shrubs $(-2.36)$ and settlement $(0.64)$ area. The severity in the watershed can be preserved by increasing the afforestation and shrubs area. Therefore, the effects due to morphometric parameters on watershed can be mitigated by planned LULC changes. These changes would reduce the productivity of land and also cause the flood due to deposition of sand in stream, etc. The results obtained for each watershed by using the morphometric and LULC analysis are quite useful for hydrologic engineers for planning and management and are as follows:

- The preservative measure can be applied at the subwatershed level to reduce soil erosion due to excessive 
runoff from rainfall (i.e., check dam, increase in forestland and shrubland, etc.)

- The new projects can be planned at the sub-watershed level in an economical way by knowing the tropology of land and LULC land feature. So in this way, most of the natural resources can be preserved/managed in a sustainable manner.

- The two extreme events such as drought and flood can be minimized by planning according to the surface land feature at sub-watershed level.

The study also revealed the benefits of remote sensing and GIS techniques for prioritization of sub-watersheds. The LULC change information in sub-watersheds is helpful in scientific planning, mitigation and management so as to preserve the water resources.

Acknowledgements The authors are thankful to ASTER Global Digital Elevation Model (GDEM) from the National Aeronautics and Space Administration (NASA) and US Geological Survey(LULC Map) used in the study. We are also thankful to unknown reviewers for their useful suggestions for the improvement of this paper.

Open Access This article is distributed under the terms of the Creative Commons Attribution 4.0 International License (http://creativeco mmons.org/licenses/by/4.0/), which permits unrestricted use, distribution, and reproduction in any medium, provided you give appropriate credit to the original author(s) and the source, provide a link to the Creative Commons license, and indicate if changes were made.

\section{References}

Arun PS, Jana R, Nathawat MS (2005) A rule based physiographic characterization of a drought prone watershed applying remote sensing and GIS. J Indian Soc Remote Sens 33(2):189-201

Astras T, Soulankellis N (1992) Contribution of digital image analysis techniques on Landsat-5 TM imageries for drainage delineation. A case study from the Olympus mountain, west Macedonia, Greece. In Proceedings of the 18th annual conference of remote sensing society. University of Dundee, Dundee, pp 15-17

Bagyaraj M, Gurugnanam B, Nagar A (2011) Significance of morphometry studies, soil characteristics, erosion phenomena and landform processes using remote sensing and GIS for Kodaikanal hills, a global biodiversity hotspot in Western Ghats, Dindigul District, Tamil Nadu, South India. Res J Environ Earth Sci 3(3):221-233

Bali R, Agarwal K, Nawaz Ali S, Rastogi S, Krishna K (2012) Drainage morphometry of Himalayan Glacio-fluvial basin, India: hydrologic and neotectonic implications. Environ Earth Sci 66(4):11631174. https://doi.org/10.1007/s12665-011-1324-1

Binjolkar P, Keshari AK (2007) Estimating geomorphological parameters using GIS for Tilaiya reservoir catchment. J Inst Eng Civ Eng Div 88(8):21-26

Biswas S, Sudhakar S, Desai VR (1999) Prioritisation of subwatersheds based on morphometric analysis of drainage basin: a remote sensing and GIS approach. J Indian Soc Remote Sens 27(3):155-166

Chandniha SK, Kansal ML (2017) Prioritization of sub-watersheds based on morphometric analysis using geospatial technique in Piperiya watershed, India. Appl Water Sci 7(1):329-338
Chopra R, Dhiman RD, Sharma PK (2005) Morphometric analysis of sub-watersheds in Gurdaspur district, Punjab using remote sensing and GIS techniques. J Indian Soc Remote Sens 33(4):531-539

Chow VT (1964) Runoff. In: Chow VT (ed) Handbook of applied hydrology. McGraw-Hill, New York, pp 14-1-14-54

Costa MH, Botta A, Cardille JA (2003) Effects of large-scale changes in land cover on the discharge of the Tocantins River, Southeastern Amazonia. J Hydrol 283(1):206-217

Danida (1988) Plan of action for integration of environmental considerations into Danish development assistance. A strategy for water resources management. Danish Ministry of Foreign Affairs, Copenhagen

Dawod G, Mirza M, Al-Ghamdi K (2012) GIS-based estimation of flood hazard impacts on road network in Makkah City, Saudi Arabia. Environ Earth Sci. https://doi.org/10.1007/s1266 5-012-1660-9

Foley JA, DeFries R, Asner GP, Barford C, Bonan G, Carpenter SR, Chapin FS et al (2005) Global consequences of land use. Science 309(5734):570-574

Gabarrón-Galeote MA, Martínez-Murillo JF, Quesada MA, RuizSinoga JD (2013) Seasonal changes in the soil hydrological and erosive response depending on aspect, vegetation type and soil water repellency in different Mediterranean microenvironments. Solid Earth 4(2):497

Gajbhiye S, Mishra SK, Pandey A (2014) Prioritizing erosion-prone area through morphometric analysis: an RS and GIS perspective. Appl Water Sci 4(1):51-61

Gravelius H (1914) Grundrifi der gesamten Gewcisserkunde. Band I: Flufikunde (Compendium of Hydrology, vol. I. Rivers, in German). Germany: Goschen, Berlin

Gupta M, Srivastava PK (2010) Integrating GIS and remote sensing for identification of groundwater potential zones in the hilly terrain of Pavagadh, Gujarat, India. Water Int 35(2):233-245

Horton RE (1932) Drainage-basin characteristics. EOS Trans Am Geophys Union 13(1):350-361

Horton RE (1945) Erosional development of streams and their drainage basins; hydrophysical approach to quantitative morphology. Geol Soc Am Bull 56(3):275-370

Iqbal M, Sajjad H (2014) Watershed prioritization using morphometric and land use/land cover parameters of Dudhganga Catchment Kashmir Valley India using spatial technology. J Geophys Remote Sens 3:1-12

Javed A, Khanday MY, Ahmed R (2009) Prioritization of sub-watersheds based on morphometric and land use analysis using remote sensing and GIS techniques. J Indian Soc Remote Sens 37(2):261

Kalnay E, Cai M (2003) Impact of urbanization and land-use change on climate. Nature 423(6939):528-531

Langbein WB (1947) Topographic characteristics of drainage basins. US Government Printing Office, USA, pp 125-157

Lieskovský J, Kenderessy P (2014) Modelling the effect of vegetation cover and different tillage practices on soil erosion in vineyards: a case study in Vráble (Slovakia) using WATEM/SEDEM. Land Degrad Dev 25(3):288-296

McCullagh P (1978) Modern concepts in geomorphology (No. 6). Oxford University Press, Oxford

Miller VC (1953) An quantitative geomorphic study of drainage basin characteristics in the clinch mountain area virginia and tennessee (no. cu-tr-3). Columbia Univ New York

Miller JR, Kochel RC (2010) Assessment of channel dynamics, instream structures and post-project channel adjustments in North Carolina and its implications to effective stream restoration. Environ Earth Sci 59(8):1681-1692

Mujumdar PP (2008) Implications of climate change for sustainable water resources management in India. Phys Chem Earth Parts $\mathrm{A} / \mathrm{B} / \mathrm{C} 33(5): 354-358$ 
Nag SK (1998) Morphometric analysis using remote sensing techniques in the Chaka sub-basin, Purulia district, West Bengal. J Indian Soc Remote Sens 26(1):69-76

Nag SK, Chakraborty S (2003) Influence of rock types and structures in the development of drainage network in hard rock area. J Indian Soc Remote Sens 31(1):25-35

Pandey PC, Sharma LK, Nathawat MS (2012) Geospatial strategy for sustainable management of municipal solid waste for growing urban environment. Environ Monit Assess 184:2419-2431

Patel DP, Gajjar CA, Srivastava PK (2013) Prioritization of Malesari mini-watersheds through morphometric analysis: a remote sensing and GIS perspective. Environ Earth Sci 69(8):2643-2656

Pielke RA, Marland G, Betts RA, Chase TN, Eastman JL, Niles JO, Running SW (2002) The influence of land-use change and landscape dynamics on the climate system: relevance to climate-change policy beyond the radiative effect of greenhouse gases. Philos Trans Royal Soc Lond A Math Phys Eng Sci 360(1797):1705-1719

Prabhakar A, Tiwari H (2015) Land use and land cover effect on groundwater storage. Model Earth Syst Environ 1(4):45

Raje D, Mujumdar PP (2009) A conditional random field-based downscaling method for assessment of climate change impact on multisite daily precipitation in the Mahanadi basin. Water Resour Res 45(10):1-20

Ratnam KN, Srivastava YK, Rao VV, Amminedu E, Murthy KSR (2005) Check dam positioning by prioritization of micro-watersheds using SYI model and morphometric analysis-remote sensing and GIS perspective. J Indian Soc Remote Sens 33(1):25-38

Rekha BV, George AV, Rita M (2011) Morphometric analysis and micro-watershed prioritization of Peruvanthanam sub-watershed, the Manimala River Basin, Kerala, South India. Environ Res Eng Manag 57(3):6-14

Sahin V, Hall MJ (1996) The effects of afforestation and deforestation on water yields. J Hydrol 178(1-4):293-309

Schumm SA (1956) Evolution of drainage systems and slopes in badlands at Perth Amboy, New Jersey. Geol Soc Am Bull 67(5):597-646

Srivastava PK, Mukherjee S, Gupta M (2010) Impact of urbanization on land use/land cover change using remote sensing and GIS: a case study. Int J Ecol Econ Stat 18(S10):106-117

Srivastava PK, Han D, Gupta M, Mukherjee S (2012) Integrated framework for monitoring groundwater pollution using a geo-graphical information system and multivariate analysis. Hydrol Sci J 57(7):1453-1472. https://doi.org/10.1080/02626667.2012.716156
Strahler AN (1952) Hypsometric (area-altitude) analysis of erosional topography. Geol Soc Am Bull 63(11):1117-1142

Strahler AN (1964) Quantitative geomorphology of drainage basins and channel networks. Section 4-II. In: Chow VT (ed) Handbook of applied hydrology. McGraw-Hill, New York, pp 4-39

Tarboton DG, Bras RL, Rodriguez-Iturbe I (1992) A physical basis for drainage density. Geomorphology 5(1):59-76

Thakur J, Srivastava PK, Singh S, Vekerdy Z (2012) Ecological monitoring of wetlands in semi-arid region of Konya closed Basin, Turkey. Reg Environ Change 12(1):133-144. https://doi.org/10.1007/ s10113-011-0241-x

Tripathi SC, Sayre KD, Kaul JN, Narang RS (2003) Growth and morphology of spring wheat (Triticum aestivum L.) culms and their association with lodging: effects of genotypes, $\mathrm{N}$ levels and ethephon. Field Crops Res 84(3):271-290

Tripathi MP, Panda RK, Raghuwanshi NS (2005) Development of effective management plans for critical sub-watersheds using SWAT model. Hydrol Processs 19:809-826

Turkelboom F, Poesen J, Trébuil G (2008) The multiple land degradation effects caused by land-use intensification in tropical steeplands: a catchment study from northern Thailand. CATENA 75(1):102-116

Verstappen HT (1983) Applied geomorphology: geomorphological surveys for environments development. Elsevier, Amsterdam

Vijith H, Satheesh R (2006) GIS based morphometric analysis of two major upland sub-watersheds of Meenachil river in Kerala. $\mathrm{J}$ Indian Soc Remote Sens 34(2):181-185

Vittala SS, Govindaiah S, Gowda HH (2004) Morphometric analysis of sub-watersheds in the Pavagada area of Tumkur district, South India using remote sensing and GIS techniques. J Indian Soc Remote Sens 32(4):351-362

Youssef AM, Pradhan B, Hassan AM (2011) Flash flood risk estimation along the St. Katherine road, and southern Sinai, Egypt using GIS based morphometry and satellite imagery. Environ Earth Sci 62(3):611-623

Publisher's Note Springer Nature remains neutral with regard to jurisdictional claims in published maps and institutional affiliations. 